\title{
PENGECETAN TROTOAR
}

\author{
NAMA : KAHARUDDIN \\ NIM: 9173770410031 \\ Email: kkahar919@gmail.com
}

1.Bentuk Kegiatan

Pengecetan Trotoar

\section{Lokasi}

Depan kantor desa dusun balang loe tarowang kec. tarowang kab. jeneponto

\section{Hari/Tanggal}

\section{Waktu}

Kamis, 22 Oktober 2020

jam 07.45

\section{Peserta yang Dilibatkan}

Peserta kklp dan tokoh masyarakat.

\section{Alasan Diadakannya}

Agar terlihat lebih indah dan rapi.

\section{Tujuan dan Manfaat}

Tujuannya: agar terlihat sepanjang jalan trotoar depan kantor desa nampak begitu indah dan bersih.

Manfaatnya : pengecetan trotoar agar menambah keindahan fungsi trotoar tersebut untuk pejalan kaki.

\section{Produk Kegiatan (Jika} Ada)

- Kuas

- Cat

- Air

- Wadah

\section{Deskripsi Kegiatan}

Sebelum memulai pengecetan terlebih dahulu kami mempersiapkan perlengkapan. Saat semua sudah siap kami memulai mengecet trotoar yang 
dikerjakan mulai pagi dan siang kami pulang untuk beristirahat, sesudah sholat asar kami pun melanjutkan pengecetan, dan disini kami dibantu oleh beberapa tokoh masyarakat setempat. 


\section{Referensi Wajib}

- HERIANTO, H., \& Amir, A. S. (2020, September 10). Pedoman Pelaksanaan Kuliah Kerja Lapangan Plus (KKLP) Mahasiswa STIE dan STKIP YAPTI Jeneponto. https://doi.org/10.31219/osf.io/7dvpk

10. Referensi Tambahan (Jika Ada) 